\title{
Human Brand Positioning: Success Mantras for Politics
}

\author{
Harish Gautam*
}

\begin{abstract}
Success in politics is not merely the outcome of policy matters; rather it is the sum total of brand positioning and marketing strategies of the political leaders. If one focuses on the acts of successful leaders in South Africa, USA, UK or even Punjab; one can clearly see the presence of branding and marketing tactics, which can be natural in some cases and professionally managed in others. This paper focuses on exploring the major factors behind human brand formation of political leaders; and suggesting the techniques of making human brand a success. Based on review of related literature and analysis of the primary data, the study brings out important factors that can lead to the success of political leaders.
\end{abstract}

Keywords: Brand positioning, Human brand, Principal Component Analysis.

\subsection{Introduction}

Marketing is a part of everyone's life and its presence can be felt in our family life as well as professional and business life. In today's world, it is hard to imagine a happy life without using tactics of marketing involving gifts, appreciation and family care; it is more or less similar to customer care techniques adopted by big companies. Marketing and branding strategies are equally applicable in politics. Today, all successful political leaders throughout the world have adopted marketing strategies for their political campaigns. They have their logos, slogans and advertising campaigns with their unique selling propositions (USPs). History is full of such examples in which the planned moves and advertising campaigns have led to success in political career. The electoral to the political leaders is just like the customer to the company.

*Assistant Professor, PG Department of Commerce \& Business Management, Doaba College, Punjab. 
The success of marketers as well the political parties depends on how sincerely they are able to implement the marketing. Like a marketer, a successful politician first understands the needs of the people as his customer (it can be the problem of inflation, infrastructure needs, problem with any type of tax) and then brings the bouquet of offerings from his political party through an advertising campaign.

Crafting a human brand is almost on the same pattern. It involves making efforts to create strong attraction towards a particular human brand/leader/celebrity. This can be professionally managed; attraction towards a product/brand/human is developed through personalised relation developed with customer/voter and positive role played by brand communities. It supports creation of the human brand through brand community (Albert M. Muniz, 2001). A brand community is a specialised, non-geographically bound community, based on a structured set of social relationships among admirers of a brand. It is specialised because at its centre lies a branded good or service. Like other communities, it is marked by a shared consciousness, rituals and traditions, and a sense of moral responsibility. Each of these qualities is, however, situated within a commercial and mass-mediated ethos, and has its own particular expression. Brand communities are participants in the brand's larger social construction and play a vital role in the brand's ultimate legacy.

\subsection{Review of literature}

Human brand is the combination of various attributes namely a name, a reputation, credibility and an image in the minds of people. Today, the political parties and leaders are dedicated in managing their human brands and building emotional bonds with the voters. Like, in the 2004 U.S. presidential election, each of the two main political parties spent in excess of $\$ 1$ billion dollars in an effort to position their candidates favourably with voters (Edsall, 2004).

Though conventionally the concept of branding is applicable to products, services, firms; however, even human beings can be managed for better positioning like celebrities or sports stars and even the political leaders. Likewise, the concept called brand is also applicable to the political leaders because they can be managed by professionals. Consultants of political parties professionally control and guide the political campaigns, the candidate's message, public appearance, endorsements, and so on, in the hope of managing perceived quality and brand image to increase "market share" at the polls (Simon, 2004). A big question that arises is that why people are attached to a human brand. A lot of research has been done in this area. 
Human brand can be formed through attraction, personalised relation and brand community. There are many reasons behind the relationship that people form with human brands. Attachment is one of the most prominent factors and others include idolatry (Houran, 2005), fandom (Leets, 1995), and celebrity worship (Dietz, 1991). Much of this research has been advanced under the title of attachment theory and its associated literature, which is both well-articulated and relevant to marketing (Kleine, 2004). Human beings experience emotions and attachments right from the cradle. Attachments are a type of strong relationship that people usually first experience as children with their parents; later in life, these attachments routinely develop with other "targets," such as human brands (Leets, 1995). When these types of relationships are experienced in reference to human brands, they are typically referred to as "secondary object" attachments and have been described as "intimacy at a distance" (Horton, 1956). Strength of attachment is the intensity of person's target specific emotional bond with a human brand and brand extension involves an ingredient brand alliance (Washbum, 2010).

The literature suggests that attachment theory can make a contribution to the success of political leaders and marketers because of the distinctive qualities of an attachment. For example, much as political leaders attempt to create relationships that are trusting, committed, and satisfied (Fournier, 1998), people routinely report elevated levels of each in their attachments to a variety of objects (Rempel, 2001). Literature points to the independence of attachment strength from trust, satisfaction, and commitment, but the correlation among these constructs suggests that understanding how to create or intensify attachments could offer both an effective and economical means of achieving the stronger marketing relations. Feelings linked to attachments are fundamental to strong brand relationships (Fournier S., 1998).

Furthermore, more intense attachments are linked to several consequences that are desirable to marketers. For example, attachments in a marketing context may prevent consumer defections (Liljander, 1995), increase voters'/consumers' forgiveness in the face of negative information (Ahluwalia, 2001), and predict brand loyalty (Thomson, 2005). If marketers/political leader understand what determines the strength of attachments, they may be in a better position to foster more durable relationships with consumers. Finally, research implies that attachments may be pivotal to understanding customer-based brand equity, in which certain brands "resonate" with consumers and indicate financial value for the firm (Ambler, 2002).

Research has considered celebrities, well-known figures, and group entities, such as sports teams or musical acts, and has documented how they are similar to interpersonal relationships in many ways. For example, people often experience 
"seeming face-to-face" relationships with human brands who are "met as if they were in the circle of one's peers" (Horton, 1956). These relationships evince many of the same expectations, cognitions, emotions, and behaviours that operate in normal interpersonal relationships to the point that a consumer/voter might view a human brand/political leader as a pleasant companion, good friend, or romantic mate (Cole, 1999).

Literature further supports how attractiveness is formed. The attraction is based on 'relatedness'. Relatedness refers to a person's need to feel a sense of closeness with others (Deci, 2000). The need for relatedness is a homonymous tendency; it is a desire to belong to a social sphere and to avoid feeling isolated (Austin, 1996). A person whose need for relatedness is satisfied is likely to report feeling "connected with and cared for by another" (La Guardia, 2000).

Today, a marketer tries to fabricate the relationship with the customer through planned phases through marketing communication, personalised communication and positive word of mouth through brand communities. The rise of modern communications made modern marketing possible. Brand communities reveal the socially situated nature of brands as something more than a summation of attitudes or impoverished critical stereotypes (Dobni, 1990). Newspapers and magazines, then radio and television, enabled marketers to project brands into national consciousness. In large degree, brands transcend geography because media transcend geography. In fact, most of the rethinking of community has had to do with the rise of mass media. Mass media demonstrated that virtually all of the hallmarks of geographic community could be simulated, if not wholly or substantially replicated, in a mass-mediated world. The changes in computer-mediated communication currently under way are no different in this regard (Fischer, 1996). The literature supports that the brand communities play pivotal role in creating the human brand by spreading the positive vibrations.

\subsection{Objectives of the study}

The present study is conducted with following objectives

- To explore the various components of human brand formation; and

- To suggest different techniques for making human brand a success.

\subsection{Methodology of Study}

\subsection{Design and data collection}

In order to achieve the objectives of the study, both primary and secondary data are analysed. With the help of review of related literature, the important components in 
the formation of human brand are brought under attention viz. attraction, relatedness and brand communities. For the primary source, 13 Likert scale statements were formulated based on literature and served in the form of questionnaire to 372 respondents to explore their preference towards a particular leader or human brand. The statements and their serial numbers are mentioned in result section of Rotated component matrix in Table 2. Convenience sampling technique was used for the purpose of data collection. The respondents were contacted at conferences and online from various states of India. The results for the study were analysed and suggestion have been incorporated in the last section of the paper.

\subsection{Scoring and Measurement of constructs}

The respondents were asked to tick their preference for all the statements on a seven point scale ranging from strongly disagree to strongly agree. The data was collected using questionnaire and it was analysed using statistical package for social sciences (SPSS). The score of the constructs were ' 0 ' for don't know and ' 1 ' for completely disagree towards ' 7 ' for completely agree. Responses were entered into a datasheet for the purpose of analysis. For the purpose of scoring MS excel and IBM SPSS was used to analyse the survey results. Likert scale was used for extracting the components of human brand formation by politicians. Principal Component Analysis technique was used to find the component loading and communalities which are important in determining the brand image formation of political leaders.

\subsection{Findings of the study}

All the statements were scored and entered into data sheets. Using SPSS, Principal Component analysis was carried out. The results have brought out four important factors which play an important role in determining the success of various politicians.

Principal Component Analysis (PCA) is a technique used for data reduction in a manner that we are able to identify the principal components without significantly affecting the explanatory power of the variables. As mentioned before, PCA was run on a 13-question questionnaire that measured human branding characteristics on 372 voters. The suitability of PCA was assessed prior to analysis. Inspection of the correlation matrix showed all variables had at least one correlation coefficient greater than 0.3 . The KMO and Bartlett's test were also carried out to examine if PCA could be applied. The results are shown in Table 1. The overall Kaiser-Meyer-Oklin (KMO) measure was 0.853 with individual $\mathrm{KMO}$ measures all greater than 0.7 , classifications of 'middling' to 
'meritorious' according to Kaiser (1974). Bartlett's test of Sphericity was statistically significant $(\mathrm{p}<0.0005)$ indicating that the data was amenable to PCA.

Table 1: KMO and Bartlett's Test

\begin{tabular}{|l|l|r|}
\hline \multicolumn{2}{|l|}{ Kaiser-Meyer-Olkin Measure of Sampling Adequacy. } & .853 \\
\hline Bartlett's Test of Sphericity & Approx. Chi-Square & 2843.800 \\
\cline { 2 - 3 } & df & 78 \\
\cline { 2 - 3 } & Sig. & 0.000 \\
\hline
\end{tabular}

On the basis of PCA, four factors were retained depending on eigenvalues and variance explained. Eigenvalue represents the total variance explained by each factor. The standard practice used is that all the factors with an Eigen value of one or more should be extracted. Table 2 clearly shows that there are four factors having eigen values more than 1 (in other words, a factor must explain at least as much of the variance if not more, than a single original variable). Thus four factors have been extracted. The solution of factor analysis gave four factors, which explained $75.75 \%$ of the total variance.

Table 2: Total Variance Explained

\begin{tabular}{|c|c|c|c|c|c|c|c|c|c|}
\hline \multirow[b]{2}{*}{$\begin{array}{l}\bar{\Xi} \\
\overline{0} \\
\stackrel{\Xi}{0} \\
\text { ठ }\end{array}$} & \multicolumn{3}{|c|}{ Initial Eigenvalues } & \multicolumn{3}{|c|}{$\begin{array}{c}\begin{array}{c}\text { Extraction Sums of } \\
\text { Squared Loadings }\end{array} \\
\end{array}$} & \multicolumn{3}{|c|}{$\begin{array}{c}\text { Rotation Sums of } \\
\text { Squared Loadings }\end{array}$} \\
\hline & 吾 & 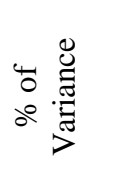 & 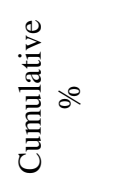 & $\stackrel{\pi}{\tilde{0}}$ & 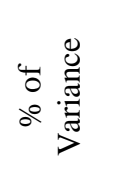 & 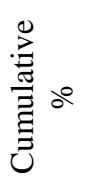 & స్ & 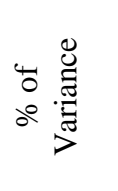 & 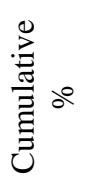 \\
\hline 1 & 5.51 & 42.43 & 42.43 & 5.51 & 42.43 & 42.43 & 3.03 & 23.33 & 23.33 \\
\hline 2 & 1.97 & 15.16 & 57.59 & 1.97 & 15.16 & 57.59 & 2.92 & 22.52 & 45.85 \\
\hline 3 & 1.33 & 10.27 & 67.86 & 1.33 & 10.27 & 67.86 & 2.65 & 20.45 & 66.30 \\
\hline 4 & 1.02 & 7.88 & 75.75 & 1.02 & 7.88 & 75.75 & 1.22 & 9.44 & 75.75 \\
\hline 5 & 0.79 & 6.08 & 81.83 & & & & & & \\
\hline 6 & 0.59 & 4.59 & 86.42 & & & & & & \\
\hline 7 & 0.42 & 3.26 & 89.69 & & & & & & \\
\hline 8 & 0.33 & 2.57 & 92.26 & & & & & & \\
\hline 9 & 0.26 & 2.07 & 94.33 & & & & & & \\
\hline 10 & 0.24 & 1.84 & 96.18 & & & & & & \\
\hline 11 & 0.22 & 1.73 & 97.91 & & & & & & \\
\hline 12 & 0.16 & 1.25 & 99.16 & & & & & & \\
\hline 13 & 0.11 & 0.83 & 100.0 & & & & & & \\
\hline
\end{tabular}


Further, PCA revealed four components that had eigenvalue greater than one and, which explained $42.43 \%, 15.16 \%, 10.27 \%$, and $7.88 \%$ of the total variance, respectively. In addition, a four-component solution met the interpretability criterion. As such, four components were retained.

The four-component solution explained $75.75 \%$ of the total variance. A Varimax orthogonal rotation was employed to aid interpretability. The rotated solution exhibited 'simple structure' (Thurstone, 1947). All the factors have been given appropriate names according to the variables that have been loaded on each factor. The interpretation of the data was consistent with the personality attributes the questionnaire was designed to measure with strong loadings of 'attraction towards politician' items on Component 1 , 'sense of relatedness' items on Component 2, 'brand community \& positive references' items on Component 3 and 'story retelling' items on Component 4. Component loadings and commonalities of the rotated solution are presented in Table 3.

\subsection{Conclusion and Suggestions}

As is evident from the study and the related literature, the human brand plays a pivotal role in determining the success of the politicians or leaders. The human brand in itself is a term related to marketing and not politics. In politics, the success of a politician is not only dependent upon his/her policy matters and vision but also how professionally he or she can portray himself/herself before the voters. The churning of the data has given the outcome of four pillars in the human brand formation viz. the attraction, relatedness, brand community and the strategy to stay in discussion.

To realise the findings of the study if we look around, we find leaders in India and abroad that have been able to position themselves successfully as a brand. One such example is Sh. Prakash Singh Badal of Punjab. He is popular in Punjab because of the elements like relatedness. 'Sangat Darshan' is one of the important factors keeping him related to the voters' community directly. He along with his team organises public meeting in various villages in which people from surrounding areas come to meet him personally, and he listens and understands the problem and tries to redress the same immediately. Similarly, the element of staying in discussion is one of the reasons that Mr. Lalu Prasad Yadav has remained a successful brand. He is known in the media for his light talks. Abroad, US President Mr. Barack Obama is a wonderful example of human brand formation. He created the history by adopting the professional approach in his political campaigning during presidential elections. He had a colour scheme, a logo and a slogan along with the personalised meetings and greetings to extend sympathy to the concerned common man. He won the hearts and was selected as a world's most 
powerful man. This is nothing but the outcome of human branding. His team works day and night to maintain a positive image as a brand community.

Table 3 :Rotated Component Matrix ${ }^{a}$

\begin{tabular}{|c|c|c|c|c|}
\hline & \multicolumn{4}{|c|}{ Component } \\
\hline & 1 & 2 & 3 & 4 \\
\hline $\begin{array}{l}\text { 3. Politicians should be Physically fit like Brack Obama } \\
\text { the President of USA }\end{array}$ & .840 & & & \\
\hline 4. Politician should be simple and with friendly attitude. & .811 & & & \\
\hline $\begin{array}{l}\text { 2. Person who does not know how to smile should not be } \\
\text { in politics. }\end{array}$ & .792 & & & \\
\hline 1. I like Political leader who gets personal. & .756 & & & \\
\hline $\begin{array}{l}\text { 8. Politician who values others opinion is better related to } \\
\text { public and parties. }\end{array}$ & & .865 & & \\
\hline $\begin{array}{l}\text { 10. The political leader who personally meets and remains } \\
\text { in touch with public is good. }\end{array}$ & & .836 & & \\
\hline $\begin{array}{l}\text { 5. We feel related to a politician if we have trust and faith } \\
\text { in him. }\end{array}$ & & .802 & & \\
\hline $\begin{array}{l}\text { 9. Politicians who believe in public is as supreme is } \\
\text { successful. }\end{array}$ & .371 & .723 & & \\
\hline $\begin{array}{l}\text { 12. Reference groups usually play important role in voters } \\
\text { decision }\end{array}$ & & & .931 & \\
\hline $\begin{array}{l}\text { 11. Positive waves during election days determines success } \\
\text { of a politician }\end{array}$ & & & .923 & \\
\hline $\begin{array}{l}\text { 13. Only good and sincere politicians can hold positive } \\
\text { feedback for long time }\end{array}$ & .348 & & .828 & \\
\hline $\begin{array}{l}\text { 7. Political leaders from common families are trustworthy } \\
\text { and popular. }\end{array}$ & & & & $\begin{array}{r}.8 \\
54\end{array}$ \\
\hline $\begin{array}{l}\text { 6. The stories of honesty, sincerity plays important role in } \\
\text { building trust. }\end{array}$ & & & & $\begin{array}{r}.6 \\
76\end{array}$ \\
\hline $\begin{array}{l}\text { Extraction Method: Principal Component Analysis; Rotatic } \\
\text { Normalization. }\end{array}$ & & & ith & \\
\hline
\end{tabular}


Last but not the least, the human branding and professionally managed branding strategies can bring a man to the chair but only the good and true leader can sustain and repeat to be elected. Thus, not only articulated elements of attractiveness, relatedness and building positive brand community will help rather one must have eligibility traits of honesty, sense of service, no corruption as to stay in the hearts of those for whom he is elected to serve i.e. the voters.

These elements of successful leaders can be applied by the managers and business leaders to rule the minds of workers and have harmonised organisation. Being on the chair, whether it is a business leader or a political leader, everyone is bestowed with some administrative powers. Only the really long-term heroes remember to prefer to manage than administer i.e. the elements of success. In other words, they do not exercise administrative powers rather work hard to rule the minds of workers or voters by staying in personal touch and following the sense of staying healthy and charming to serve honestly.

\section{References}

Ahluwalia, R. H. (2001). The Moderating Role of Commitment on the Spillover Effect of Marketing Communications. Journal of Marketing Research, 458-70.

Albert M. Muniz, J. a. (2001, March). Brand Community. Journal of Consumer Research, 27(4), 412-432.

Ambler, T. C. (2002). Relating Brand and Customer Perspectives on Marketing Management. Journal of Service Research, 13-25.

Austin, J. T. (1996). Goal Constructs in Psychology: Structure, Process and Content. Psychological Bulletin, 338-75.

Cole, T. a. (1999). Attachment Styles and Intimate Television Viewing: Insecurely Forming Relationships in a Parasocial Way. Journal of Social and Personal Relationships, 16(4), 455-511.

Deci, E. L. (2000). The 'What' and 'Why' of Goal Pursuits: Human Needs and the SelfDetermination of Behavior. Psychological Inquiry, 227-68. 
70 | MANTHAN: Journal of Commerce and Management, Vol. 1, Issue 2

Dietz, P. Er. (1991). Threatening and Other- wise Inappropriate Letters to Hollywood Celebrities. Journal of Forensic Sciences, 36(1), 185-29.

Dobni, D. A. (1990). In Search of Brand Image: A Foundation Analysis. Advances in Consumer Research, 17, 110-119.

Edsall, T. B. (2004, December 30). GOP Got More Bang for Its Billion, Analysis Shows. Washington Post, p. A01.

Fischer, E. J. (1996). Creating or Escaping Community? An Exploratory Study of Internet Consumers' Behaviors. Advances in Consumer Research, 23, 178-182.

Fournier, S. (1998). Consumers and Their Brands: Developing RelationshipTheory in Consumer Research. Journal of Consumer Research, 343-73.

Fournier, S. D. (1998). Prevent ing the Premature Death of Relationship Marketing. Harvard Business Review, 42-51.

Horton, D. A. (1956). Mass Communication and Para-Social Interaction: Observations on Intimacy at a Distance. Psychiatry: Journal for the Study of Interpersonal Processes, 215-29.

Houran, J. S. (2005). Bound- ary Functioning in Celebrity Worshippers. Personality and Individual Differences, 38(1), 237-48.

Kleine, S. S. (2004). An Inte- grative Review of Material Possession Attachment. Academy of Marketing Science Review, 1-39.

La Guardia, J. G. (2000). Within-Person Variation in Security of Attachment: A SelfDetermination Theory Perspective on Attachment, Need-Fulfillment and Well-Being. Journal of Personality and Social Psychology, 367-84.

Leets, L. G. (1995). FANS: Exploring Expressed Motivations of Contacting Celebrities. Journal of Language and Social Psychology, 102-123.

Liljander, V. A. (1995). The Nature of Customer Relationships in Services. Advances in Services Marketing and Management, 141-67. 
Rempel, J. K. (2001). Trust and Communicated Attributions in Close Relationships. Journal of Personality and Social Psychology, 57-64.

Simon, R. D. (2004, August 9). In the House of the Believers. US News and World Report.

Thomson, M. D. (2005). The Ties that Bind: Measuring the Strength of Consumers' Emotional Attachments to Brands. Journal of Consumer Psychology, 77-91.

Washbum, J. H. (2010). Co-Branding: Brand Equity and Trial Effects. Journal of Consumer Marketing, 591-604. 